\title{
Malignancy in mature cystic teratoma of the ovary: A rarity
}

\author{
Das A. ${ }^{1}$, Panda S. ${ }^{2}$, Nandwani M. ${ }^{3}$, Singh S.A. ${ }^{4}$, Marbaniang $E^{5}$ \\ ${ }^{1}$ Dr. Ananya Das, Assistant Professor, ${ }^{2}$ Dr. Subrat Panda, Associate Professor, ${ }^{3}$ Dr. Megha Nandwani, PG student, ${ }^{4}$ Prof. A. \\ Santa Singh, Professor \& Head, ${ }^{5}$ Dr. Evarisalin Marbaniang, Assistant Professor, all authors are attached with Department of \\ Pathology, North Eastern Indira Gandhi Regional Institute of Health and Medical, Shillong, Meghalaya, India.
}

Address for Correspondence: Dr. Subrat Panda, Associate Professor, Department of Obstetrics \& Gynecology, NEIGRIHMS. Email ID: pandadrsubrat@rediffmail.com

\begin{abstract}
Mature cystic teratomas (MCTs) are the most commonly seen germ cell tumors of the ovaries. In postmenopausal women, they mostly undergo malignant. The most commonly seen malignancy in these type of germ cell tumors is squamous cell carcinoma of the ovary. An 83-year-old postmenopausal woman presented to us with a similar but rare clinical course that is discussed here.
\end{abstract}

Keywords: Mature cystic teratoma; Squamous cell carcinoma; Germ cell tumour

\section{Introduction}

It has been reported that only $2 \%$ of the cases diagnosed with mature cystic teratoma undergo a malignant change [1]. $75 \%$ of these cases with this type of germ cell tumor are further diagnosed to have squamous cell carcinoma [2]. The survival rate in these cases is around 15 to $30 \%$ over a period of 5 years [3]. The staging and histopathology report do not seem to have an effect on the survival rates. Management of these tumors is surgery.
Also, the prognosis can be improved with adjuvant radiotherapy and polychemotherapy. The women who commonly undergo this malignant transformation are in the postmenopausal age group [4]. There are no specific tumor markers for this condition. Thus, a postoperative diagnosis is made most of the times [5]. The case report which is presented below is about the rare malignant transformation in mature cystic teratoma of the ovary in an eighty three year old postmenopausal women.

\section{Case Report}

A women 83 years old para 10 live 4 (P10L4) was referred to our hospital with the complaint of inability to walk since 5 months. She was admitted in the neurosurgery department and MRI showed a large well defined cystic lesion in the region of the POD (pouch of douglas) measuring $10.9 * 9.1 * 9 \mathrm{cms}$.

The lesion showed fat fluid level with few thick septations within. There was a focal solid component attached posteriorly measuring $1.9 * 2.4 * 2.2 \mathrm{cms}$. Features were suggestive of teratoma possibly mature teratoma. There was also collapse of L5 vertebra with fracture of the superior endplate and marrow edema in fracture region.

Patient was then shifted to Gynecology ward with the diagnosis of pelvic mass with vertebral metastasis. She also had mild pain lower abdomen with urinary incontinence since a year. She was $\mathrm{P}_{10} \mathrm{~L}_{4}$ with all normal vaginal deliveries and menopausal since 27 years.

Per abdomen examination showed abdominal distension with suprapubic mass of about $14 \mathrm{~cm}$ x16 cm irregular and firm in consistency, mobility was restricted, lower margin could not be appreciated. On per speculum examination, vagina was atrophied and cervix could not be visualized. Per vaginum examination showed bilateral fornices full with stony hard lump of around 14 to 16 weeks.

Manuscript received: $6^{\text {th }}$ March 2017

Reviewed: $16^{\text {th }}$ March 2017

Author Corrected: $25^{\text {th }}$ March 2017

Accepted for Publication: $31^{\text {st }}$ March 2017

Obsgyne Review: Journal of Obstetrics and Gynecology Available online at: www.medresearch.in 13| P a g e 


\section{Investigations.}

\section{Case Report}

\begin{tabular}{|c|c|c|}
\hline Tests & Values & Normal values \\
\hline CEA2 & $35.44 \mathrm{ng} / \mathrm{ml}$ & $<=3 \mathrm{ng} / \mathrm{ml}$ \\
\hline OV125 & $58.7 \mathrm{U} / \mathrm{ml}$ & $140-280 \mathrm{U} / \mathrm{L}$ \\
\hline LDH & 162 & $<5 \mathrm{mIU} / \mathrm{ml}$ \\
\hline Beta HcG & $3.7 \mathrm{mIU} / \mathrm{ml}$ & $<10 \mathrm{ng} / \mathrm{ml}$ \\
\hline Alpha Feto protien & 2.26 & $\mathrm{NILM}$ \\
\hline Pap smear & Low grade intraepithelial lesion & $12-15.5 \mathrm{gm} \%, 36-48 \%$ \\
\hline Hb,PCV & $12.3 \mathrm{gm} \%, 36.7 \%$ & $4000-10,000$ \\
\hline TLC & 5200 & - \\
\hline ECHO,ECG & Normal & $<200 \mathrm{mg} / \mathrm{dl}$ \\
\hline RBS & $114 \mathrm{mg} / \mathrm{dl}$ & $7-20 \mathrm{mg} / \mathrm{dl}, 0.6-1.1 \mathrm{mg} / \mathrm{dl}$ \\
\hline Urea, Creat & $21,0.6 \mathrm{mg} / \mathrm{dl}$ & $5-40 \mathrm{U} / 1,7-56 \mathrm{U} / 1$ \\
\hline SGOT,SGPT & $14,10 \mathrm{U} / 1$ & \\
\hline
\end{tabular}

Patient was then taken up for surgery. Total abdominal hysterectomy with bilateral salpingo-oopherectomy under general anaesthesia was done. Intraoperatively, uterus was atrophied, right ovary showed a dermoid cyst of $8 * 9 \mathrm{cms}$ that was adherent to the pouch of douglas. Left side showed a solid cyst teratoma of $3 * 2 \mathrm{cms}$.

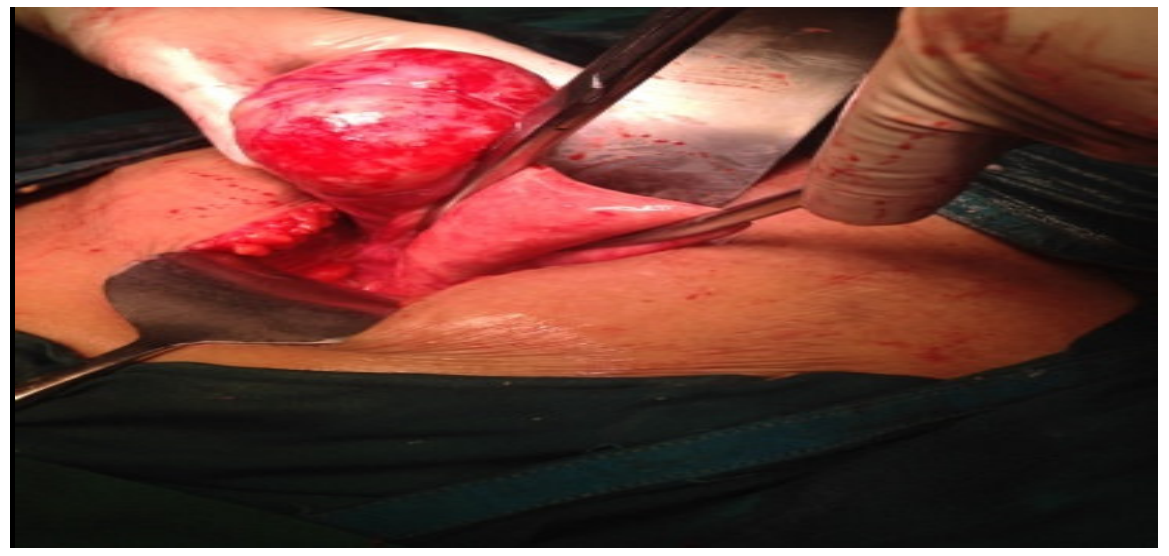

Fig.-1: Intraoperative picture of the tumour and diseased ovary

Histopatholgy report showed right ovarian teratoma with malignant transformation of epithelial component into squamous cell carcinoma, left ovarian mature cystic teratoma with atrophied uterus and chronic cervicitis with squamous metaplasia. Bilateral fallopian tubes were unremarkable.

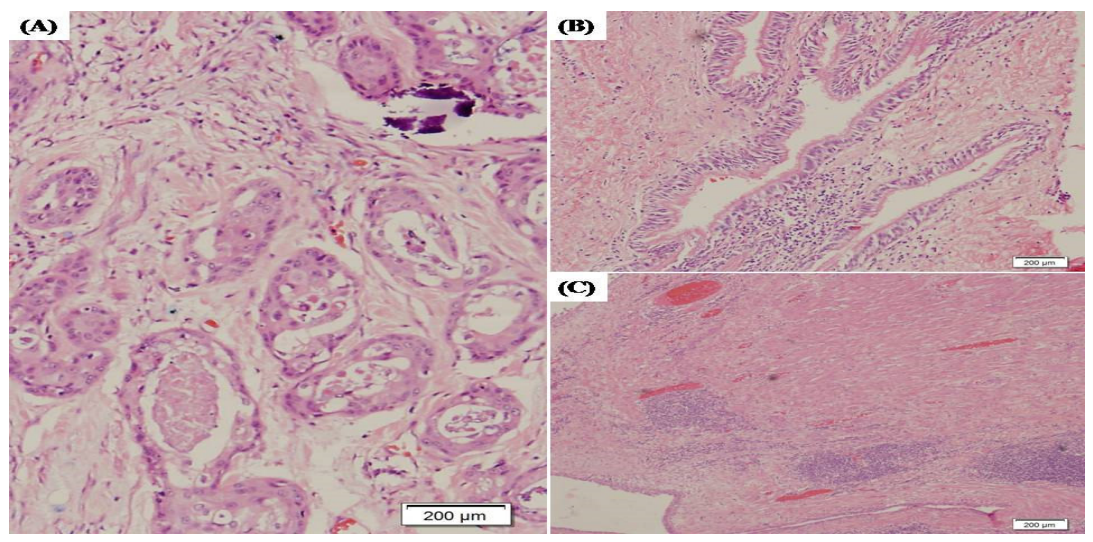

Fig.2: A- Squamous cell carcinoma (H \& E, 200X), B-Benign epithelial component (H\&E, 40X), C-Benign mesenchymal component (H\&E, 40X) 
Case Report

Patient was then started on anti tubercular therapy for L4 L5 tubercular diskitis. No sign of metastasis was seen. She was also advised short course of postoperative chemotherapy and regular follow up.

\section{Discussion}

Desouki MM et al [6] in their study reviewed medical records of patients diagnosed with ovarian teratomas from 2002 to 2011. Out of the 956 patients diagnosed with ovarian teratoma in their study, only 316 patients that is $33.1 \%$ underwent an intraoperative consultation, out of which 211 cases that is $66.8 \%$ were taken up for gross evaluation intrapoperatively. Out of these 211 cases, 4 were found to be malignant on final diagnosis. Also, frozen section was taken for 105 patients $(33.2 \%)$ of the 316 patients and 12 were malignant on final diagnosis.

Thus, a total of 26 patients that is $2.7 \%$ were found to be malignant and the average age of these patients was 48.7 years. In this study, the mucinous and serous borderline tumors were more common and not squamous cell carcinomas.

Also, a study was conducted by JS et al [7] from January 1961 to June 2009 on 44 patients with a diagnosis of mature cystic teratoma of the ovary. These patients had a median age of 48 years, and the mean size of the tumor was $16+-6 \mathrm{cms}$. Out of the 44 patients, 37 cases were found to be malignant, and in these 37 patients, 32 were diagnosed with squamous cell carcinoma that is $73 \%$. The other 5 cases had increased levels of squamous cell carcinoma antigen. 3 of the 37 cases were diagnosed to be malignant on image examinations that is $8 \%$. 22 patients were diagnosed with unilateral involvement of the ovary, in which 10 had an intact capsule and 12 had ruptured capsule. Also, 22 patients had disease extension beyond the ovaries, and 27 patients were not found to have any residual disease after primary surgery. The survival rates of patients with residual disease was 10 months and without residual disease was 84 months.

Case reports of various types have also been published from all around the world. Kahraman $\mathrm{K}$ et al [8] reviewed a similar case along with synchronous occurrence of endometrial adenocarcinoma.

Kalampokas E [9] et al also studied the same in a 53 year old premenopausal women. Do VT [10] et al reported the same condition in a 44 year old female who received chemotherapy and pelvic radiotherapy for the tumor. After 3 years of follow up, no residual disease or any complication was seen.

In our case report, the age of the patient was 83 years and the presentation was bilateral although malignant transformation was confined to only one ovary.

\section{Conclusion}

A timely diagnosis with prompt management can help in improving the prognosis of this rare malignant transformation seen in mature cystic teratoma of the ovary. Also, postoperative chemotherapy and radiotherapy can help in reducing the incidence of any residual disease or complications.

\section{Funding: Nil, Conflict of interest: Nil Permission from IRB: Yes}

\section{References}

1. Patni R. Squamous cell carcinoma arising in mature cystic teratoma of ovary. J Midlife Health. 2014 Oct;5(4): 195-7. doi: 10.4103/0976-7800.145169.

2. Amidzić J, Dolai M, Kaćanski MM, Gluhović A, Ilić J, Bozanić S. Squamous cell carcinoma in mature cystic teratoma of the ovary. Med Pregl. 2012 Sep-Oct;65(9-10): 429-31.

3. Aïda AK, Sana BS, Essia S, Carole GB, Ahlem LB, Amel T, Sabah MR. [Malignant degeneration of mature benign teratoma of the ovary: a case report]. Tunis Med. 2005 Nov;83(11):710-3.

4. Hackethal A, Brueggmann D, Bohlmann MK, Franke FE, Tinneberg HR, Münstedt K. Squamous-cell carcinoma in mature cystic teratoma of the ovary: systematic review and analysis of published data. Lancet Oncol. 2008 Dec;9(12):1173-80. doi: 10.1016/S14702045 (08)70306-1.

5. Hurwitz JL, Fenton A, McCluggage WG, McKenna S. Squamous cell carcinoma arising in a dermoid cyst of the ovary: a case series. BJOG. 2007 Oct; 114 (10): 1283-7.

6. Desouki MM, Fadare O, Chamberlain BK, Shakir N, Kanbour-Shakir .A Malignancy associated with ovarian teratomas: frequency, histotypes, and diagnostic accuracy of intraoperative consultation. Ann Diagn Pathol. 2015 Jun; 19(3):103-106.

7. An JS, Wu LY, Li XG, Zhang R, Song Y, Ma SK, Liu LY, Hong WJ. Clinical analysis of 44 cases with malignant transformation of ovarian mature cystic teratoma. Zhonghua Fu Chan Ke Za Zhi. 2013 Feb;48 (2): 123-128. 


\section{Case Report}

8. Kahraman K, Cetinkaya SE, Kankaya D, Dünder I, Söylemez F. Squamous cell carcinoma arising from mature cystic teratoma of the ovary with synchronous endometrial adenocarcinoma. J Obstet Gynaecol Res. 2011 Feb; 37(2):146-150.

9. Kalampokas E, Boutas I, Kairi-Vasilatou E, Salakos N, Panoulis K, Aravantinos L, Damaskos C, Kalampokas T, Deligeoroglou E. A rare case report of squamous-cell carcinoma arising from mature cystic teratoma of ovary. G Chir. 2014 Sep-Oct;35(9-10):241-5.

10. Do VT, Thomas GM, Bjarnason GA. Postoperative concurrent chronomodulated 5-fluorouracil/leucovorin infusion and pelvic radiotherapy for squamous cell carcinoma of the ovary arising from mature cystic teratoma. Int J Gynecol Cancer. 2001;11:418-421.

\section{How to cite this article?}

Das A, Panda S, Nandwani M, Singh S.A, Marbaniang E. Malignancy in mature cystic teratoma of the ovary: A rarity. Obs Rev:J obstet Gynecol 2017;3(1):13-16.doi: 10.17511/joog.2017.i01.03. 